\title{
University of Groningen
}

\section{Public private partnerships in transport}

Verweij, Stefan

Published in:

Transport Reviews

DOI:

10.1080/01441647.2017.1289993

IMPORTANT NOTE: You are advised to consult the publisher's version (publisher's PDF) if you wish to cite from it. Please check the document version below.

\section{Document Version}

Early version, also known as pre-print

Publication date:

2017

Link to publication in University of Groningen/UMCG research database

Citation for published version (APA):

Verweij, S. (2017). Public private partnerships in transport: trends and theory. Transport Reviews, 37(5), 685-687. https://doi.org/10.1080/01441647.2017.1289993

\section{Copyright}

Other than for strictly personal use, it is not permitted to download or to forward/distribute the text or part of it without the consent of the author(s) and/or copyright holder(s), unless the work is under an open content license (like Creative Commons).

The publication may also be distributed here under the terms of Article 25fa of the Dutch Copyright Act, indicated by the "Taverne" license. More information can be found on the University of Groningen website: https://www.rug.nl/library/open-access/self-archiving-pure/taverneamendment.

Take-down policy

If you believe that this document breaches copyright please contact us providing details, and we will remove access to the work immediately and investigate your claim.

Downloaded from the University of Groningen/UMCG research database (Pure): http://www.rug.nl/research/portal. For technical reasons the number of authors shown on this cover page is limited to 10 maximum. 


\title{
Public Private Partnerships in Transport: Trends and Theory
}

\author{
Stefan Verweij
}

This is the pre-peer reviewed version of the article. The Version of Record of this manuscript has been published and is available in Transport Reviews (2017): http://dx.doi.org/10.1080/01441647.2017.1289993.

Verweij, S. (2017). Public Private Partnerships in Transport: Trends and Theory. Transport Review, 37 (5), 685-687.

\section{Book Review}

Athena Roumboutsos, Public Private Partnerships in Transport: Trends and Theory (London, Routledge, 2016) 391 pp., £95.00, hardback, ISBN 9781138898165.

Public-Private Partnerships (often abbreviated as PPPs or P3s) continue to attract considerable attention worldwide as a governance model for delivering public services, particularly in the transport sector: in Europe, the transport infrastructure sector represents about 60\% of the PPP market (European PPP Expertise Centre 2016). PPPs are popular with policymakers since they allow the public sector to benefit from private sector capacities and resources, leading to increased quality of transport infrastructure development and management, for lower prices, and with faster delivery times.

Compared to traditional procurement of transport infrastructure services, however, PPPs are complex governance arrangements involving many stakeholders with often conflicting interest, and are hence challenging to implement (De Schepper et al. 2014, e.g. Verweij 2015a). Unsurprisingly then, the increasing popularity of PPPs is accompanied with calls for more research into their functioning and performance. In this respect, scholars (see e.g. Hodge et al. 2010, Jeffares et al. 2013, Hueskes et al. 2016) have recently pointed out that in particular more research is needed that, inter alia, brings together PPP experiences from different countries, that investigates not just the promises of PPPs but also their actual implementation and actual outcomes, that applies systematic and comparative methods to these purposes, and that considers PPP performance and outcomes from the perspective of not just the public sector, but from the wider variety of stakeholders involved in PPPs.

The edited volume Public Private Partnerships in Transport: Trends and Theory (Roumboutsos 2016) addresses these research gaps. The book reports on the results of the COST Action TU1001, a joint effort of European scholars to advance the theoretical development of the PPP model. The effort is focussed on decision-making for PPPs, the identification of success factors to improve PPP performance, and on the efficiency implications of PPPs (2016, p. xix). This was done by exploiting case 
study data, collected based on a standardized protocol, and then conducting crosscountry analyses of these data (see also Roumboutsos 2015 in this journal). The book aims to cater to policymakers, practitioners, and the academic community with an already fundamental understanding of PPPs (2016, p. xix).

The book is clearly structured in four parts, which subsequently address the following PPP themes: (1) national implementation context, (2) decision-making models, (3) performance, and (4) efficiency. Each part commences with an introductory chapter that highlights the major issues being addressed and closes with a chapter on conclusions, future research, and policy recommendations.

The book features various interesting and relevant observations and conclusions. One of them is that it argues that "current decision tools are predominantly based on financial concepts of VfM (Value-for-Money, red.), while the individual perspectives and objectives of the different stakeholders are often disregarded" (2016, p. 160). This important issue of the multifaceted nature of PPP performance, due to the involvement of a wide variety of stakeholders, is addressed in some depth in Part 3 of the book (2016, p. 167ff.). Another interesting issue that is addressed concerns the tension between standardisation and contextualisation. In fact, "the topic of standardisation versus contextualisation in its various expressions" resurfaces throughout the book, it is said (2016, p. 4). This is an important issue indeed. It is increasingly recognised, as also acknowledged by the book, that some level of standardisation is required for PPP decision-making and projects to be efficient, transparent, and accountable. At the same time, however, PPPs have to be responsive to local, specific needs (contextualisation) and offer tailor-made solutions in order to be effective. This tension is increasingly recognized but generally little researched. Chapter 18 is salient in that it is the only one in the book that actually explicitly delves into this issue. It explores how the respective drivers for standardisation and contextualisation have impacted the PPP decision-making and governance at the national, programmatic, and project levels in three countries: the Netherlands, Australia, and the United States. However, real research progress in the analysis of which balance between standardisation and contextualisation is required under different circumstances is yet to be made.

This being an academic review, it is only natural that some weaknesses of the book are addressed here as well. First of all, although the authors' efforts in bringing together PPP experiences from different countries in a comparative manner is commendable, the book hardly goes beyond data/case description and into the analysis of causal patterns. That is, many chapters are very descriptive, identifying cross-country differences and trends by presenting data and cases in a systematic way. However, the book lacks an analysis of causal trends. For instance, it features various chapters on performance of PPPs, but no rigorous empirical research is presented that shows the variables or conditions that causally affect performance. One reason for this lack may be the choices of methods applied. Future analytical efforts on the COST Action data may benefit from the application of more causal comparative methods, such as Qualitative Comparative Analysis (Jordan et al. 2011, Verweij and Gerrits 2013). A second point is that, although clearly structured, the 
book feels unbalanced at some points. For instance, whilst some chapters apply rigorous comparative methods (e.g. Chapters 2 and 3), other chapters lack this rigour and failed to provide even a justification of the case selection or have not applied a systematic method for the comparison of cases. Thirdly, the four concluding chapters of the four respective parts in the book are also quite different: some of the chapters are rather long and provide conclusions and recommendations that do not always clearly stem from the chapters that constitute the part and that therefore feel a bit farfetched (Chapter 5), whilst other concluding chapters are very brief and do not really add anything to the chapters in their part (e.g. Chapter 16).

In conclusion, the book is well-suited for the target audience and it provides insights in some theoretical underpinnings and recent trends of PPPs in Europe. Although more effort could have been put in making the book a more coherent read, both in terms of theoretical and methodological rigour and in terms of reflection on the chapter's findings and conclusions, it does strengthen the agenda for a number of relevant issues in PPP research and practice, most evidently the tension between standardisation and contextualisation and the comparison of cross-country data.

\section{References}

De Schepper, S., Dooms, M., and Haezendonck, E., 2014. Stakeholder dynamics and responsibilities in public-private partnerships: A mixed experience. International Journal of Project Management, 32 (7), 1210-1222.

European PPP Expertise Centre, 2016. Market update: Review of the European PPP market in 2015. Luxembourg: European Investment Bank.

Hodge, G.A., Greve, C., and Boardman, A.E., eds., 2010. International handbook on public-private partnerships. Cheltenham: Edward Elgar.

Hueskes, M., Koppenjan, J.F.M., and Verweij, S., 2016. Publiek-private samenwerking in Nederland en Vlaanderen: Een review van veertien proefschriften. Bestuurskunde, 25 (2), 90-104.

Jeffares, S., Sullivan, H., and Bovaird, T., 2013. Beyond the contract: The challenge of evaluating the performance(s) of public-private partnerships. In: C. Greve and G.A. Hodge, eds. Rethinking public-private partnerships: Strategies for turbulent times. New York: Routledge, 166-187.

Jordan, E., Gross, M.E., Javernick-Will, A.N., and Garvin, M.J., 2011. Use and misuse of qualitative comparative analysis. Construction Management and Economics, 29 (11), 1159-1173.

Roumboutsos, A., 2015. Public private partnerships in transport infrastructure: An international review. Transport Reviews, 35 (2), 111-117.

Verweij, S., 2015a. Achieving satisfaction when implementing PPP transportation infrastructure projects: A qualitative comparative analysis of the A15 highway DBFM project. International Journal of Project Management, 33 (1), 189-200.

Verweij, S. and Gerrits, L.M., 2013. Understanding and researching complexity with qualitative comparative analysis: Evaluating transportation infrastructure projects. Evaluation, 19 (1), 40-55. 